\title{
Stability Analysis of Yield and Its Components for Promising Barley Genotypes under Water Stress and Saline Affected Fields
}

\author{
EL-Shawy, E.E.; Sally E. El-wakeel and Ashgan M. Abd El-Azeem \\ Barley Research Dep., Field Crops Research Institute, ARC, Egypt \\ Corresponding author: sayedelshawy@gmail.com
}

\begin{abstract}
The objective of this investigation aim was to evaluate twenty barley genotypes under different environments for testing stability of their performance. Where, development of any crop genotypes with adaptation to changes is one of most important goal of breeding program. This study examined twenty barley genotypes over different three environments; normal, water stress and salt stress. The normal and water stress experiments were conducted at Sakha while salt stress experiment was conducted at the El-Hosinia station during two seasons (2014/2015 and 2015/2016). The combined analysis of variance for environments, genotypes and (Genotypes x Environments) interaction was highly significant for all studied genotypes, suggesting differential responses of the genotypes and the need to stability analysis. Results revealed that highly yielding genotypes can also be stable. Giza 133 and Line 7 had desired performance (grain yield) compared to the grand mean, regression coefficient $\left(b_{i}\right)$ did not differ significantly from unity and had low deviation from regression $\left(\mathrm{S}^{2} \mathrm{~d}\right)$ values, indicating the role of linear portion of $\mathrm{G} \times \mathrm{E}$ interaction in the performance of these genotypes. Giza 130, Line 4, Line 5 and Line 8 had the lowest $\left(b_{i}\right)$ values which were more adapted to unfavorable environments, whereas Giza 132, Line 3 and Line 6 were input sensitive and adapted to high potential environments.
\end{abstract}

Keywords: Barley, stability, grain yield, water stress, salt stress.

\section{Introduction}

Barley crop is growing in a large scale in the rainfed areas in North coastal region and in the newly reclaimed saline lands in Egypt. Most of these lands are suffering from water shortage, soil salinity and low soil fertility. Only about $2.5 \%$ of the total area of Egypt is cultivated, with about $30 \%$ of the cultivated lands affected by salinity. In addition, about (400 000 ha) suffer from waterlogging. Egypt has about 120 000 ha in the North West Coast (NWC) region and about 40000 ha in North Sinai. The annual precipitation is about $135 \mathrm{~mm}$ in NWC, and slightly higher in North Sinai (Noaman 2008).

Barley is recommended to grow under drought and saline soil conditions. Therefore, barley cultivars developed for these areas should be drought tolerant and stable under harsh conditions. El-Sayed (2002), Ahmed et al., (2003) and Noaman et al., (2006), reported that it is possible to identify high yield potential barley genotypes under sever stresses with high yield stability. Total harvested areas in Egypt season 2016/2017 amount to 175,270 feddan with an annual production of approximately $239,666.7$ ton.

Therefore, the main objective of this study was to identify promising barley genotypes that are able to produce high yield and are more tolerant to water stress and salinity conditions.

\section{Materials and Methods}

Twenty barley six-row genotypes were used in the study, including 5 covered local varieties, 5 hulles local varieties and 10 promising Egyptian lines. The list of the twenty genotypes and pedigree are presented in Table $\mathbf{1}$.

The twenty barley genotypes were evaluated at different three environments; normal, water stress and salt stress. The normal and water stress experiments were conducted at Sakha Agricultural Research Station while salt stress experiment was conducted at the El-Hosinia Agricultural Research Station (salinity affected soils), during two seasons (2014/2015 and 2015/2016).

The normal experiment irrigated three times, while the second one included only the sowing irrigation (water stress). Grains were hand drilled at the recommended sowing rate of barley in the irrigated land in Egypt $\left(50 \mathrm{~kg} \mathrm{fed}^{-1}\right)$. Each genotype was sown in six rows of $3.5 \mathrm{~m}$, spaced with $20 \mathrm{~cm}$ among rows (plot area $4.2 \mathrm{~m}^{2}$ ). These experiments were laid out in a RCBD with three replications. Sowing was done in first of December in both seasons.

Data were collected from each plot on random sample for each genotype, days to maturity, plant height $(\mathrm{cm})$, spike length $(\mathrm{cm})$, No. of spikes $\mathrm{m}^{-2}$, No. of grains spike- biological yield $\left(\mathrm{kg} \mathrm{fed}^{-1}\right)$, grain yield $\left(\mathrm{kg} \mathrm{fed}^{-1}\right)$ and 1000-grain weight $(\mathrm{g})$ were recorded. 
Soil samples were randomly taken from the experimental area at a depth of 0 to $30 \mathrm{~cm}$ from soil surface before barley sowing. The soil properties are shown in Table 2. Monthly temperature and rainfed shown in Table 3. Water application was mentiored via a water meter as shown in Table 4.

Table 1. Name and pedigree of the studied barley genotypes.

\begin{tabular}{lll}
\hline No. & Genotype & Pedigree/Cross Name \\
\hline 1 & Giza 123 & Giza 117//FAO86 \\
2 & Giza 126 & BaladiBahteem/SD729-por12762-Bc \\
3 & Giza 132 & Rihane-05//As46/Aths*2" Aths/ Lignee686 \\
4 & Giza 133 & Carbo/Gustoe \\
5 & Giza 134 & Alanda-01/4/WI 2291/3/Api/CM67//L2966-69 \\
6 & Giza 129 & Deir Alla 106/Cel//As46/Aths*2 \\
7 & Giza 130 & "Comp.cross"229//Bco.Mr./ DZ0231 /3 /Deir Alla106 \\
8 & Giza 131 & CM67-B/CENTENO//CAM- B /3/ ROW906.73 /4 / GLORIA-BAR / COME-B/5/ \\
9 & Giza 135 & ZARZAN/BERMEJO/4/DS4931//GLORIA-BAR/COPAL/3/SEN/5/AYAROS \\
& & PLAISANT/7/CLN-B/LIGEE640/3/S.P-B//GLORIA-BAR/COME-B/5/FALCON- \\
10 & Giza 136 & BAR/6/LINO CLN-B/A/S.P-B/LIGNEE640/3/S.P-B//GLORIA- BAR/COME- \\
& & B/5/FALCON-BAR/6/LINO \\
11 & Line 1 & Giza 117/4/4/Mr 25-84/Att/3/Mari/Aths//Bc \\
12 & Line 2 & Giza 117/4/API/CM67-B//ORE/3/LBIRAN/UNA80//.... \\
13 & Line 3 & Giza 118/3/Aths/Lignee686//ACSAD618 \\
14 & Line 4 & Giza 121/3/Alanda/Hamra-01//Gloria 'S'/Copal 's' \\
15 & Line 5 & Giza 121/3/Alanda/Hamra-01//Gloria 'S'/Copal 's' \\
16 & Line 6 & Giza 123/3/Alanda/Hamra-01//Alanda-01 \\
17 & Line 7 & Giza125/5/ACSAD1182/4/Arr/ESP//Alger/Ceres362-1-1/3/WI \\
18 & Line 8 & Giza126/5/Apm/HC1905//Robur/3/Arr/4/Baca 'S'/3/AC253//CI08887/CI05761 \\
19 & Line 9 & Giza 2000/3/Alanda/Hamra-01//Alanda-01 \\
20 & Line 10 & C.C 89/Alanda/Zafraa//Gloeia'S'/Copal 's' \\
\hline
\end{tabular}

Table 2. Some mechanical and chemical analysis before sowing at 0-30 cm depth for Sakha and El-Hosinia Research stations during 2014/2015 and 2015/2016 seasons.

\begin{tabular}{|c|c|c|c|c|}
\hline \multirow{2}{*}{ Soil Properties } & \multicolumn{2}{|c|}{ Sakha } & \multicolumn{2}{|c|}{ El-Hosinia } \\
\hline & $2014 / 2015$ & $2015 / 2016$ & $2014 / 2015$ & $2015 / 2016$ \\
\hline Sand & 13.2 & 16.2 & 17.9 & 10.5 \\
\hline Silt & 37.5 & 36.3 & 35.3 & 39.6 \\
\hline Clay & 49.3 & 47.5 & 46.8 & 49.9 \\
\hline \multicolumn{5}{|c|}{ Chemical analysis } \\
\hline pH & 7.9 & 8.15 & 9.3 & 8.5 \\
\hline $\mathrm{EC} \mathrm{dSm}^{-1}$ & 2.2 & 2.1 & 15.7 & 12.3 \\
\hline ESP & 7.3 & 7.6 & 13.2 & 13.9 \\
\hline
\end{tabular}

Table 3. Monthly mean of air temperature $\left(\mathrm{At}^{\mathrm{O}} \mathrm{C}\right)$ and rainfed $(\mathrm{mm} / \mathrm{month})$ in winter seasons $2014 / 2015$ and 2015/2016 at Sakha and El-Hosinia sites.

\begin{tabular}{|c|c|c|c|c|c|c|c|c|c|c|c|c|}
\hline \multirow{3}{*}{ Month } & \multicolumn{4}{|c|}{${ }^{\text {At }}{ }^{\circ} \mathrm{C} 2014 / 2015$} & \multicolumn{4}{|c|}{$\mathrm{At}^{\mathrm{O}} \mathrm{C} 2015 / 2016$} & \multicolumn{4}{|c|}{ Rainfed (mm) } \\
\hline & \multicolumn{2}{|c|}{ Sakha } & \multicolumn{2}{|c|}{ El-Hosinia } & \multicolumn{2}{|c|}{ Sakha } & \multicolumn{2}{|c|}{ El-Hosinia } & \multicolumn{2}{|c|}{ Sakha } & \multicolumn{2}{|c|}{ El-Hosinia } \\
\hline & Max. & Min. & Max. & Min. & Max. & Min. & Max. & Min. & $2014 / 2015$ & $2015 / 2016$ & $2014 / 201$ & $2015 / 2016$ \\
\hline December & 19 & 11 & 20 & 10 & 20 & 13 & 20 & 14 & 35 & 15 & 47 & 15 \\
\hline January & 17 & 6 & 19 & 9 & 17 & 10 & 18 & 11 & 18 & 12 & 49 & 33 \\
\hline February & 21 & 8 & 22 & 11 & 22 & 11 & 20 & 13 & 23 & 5 & 14 & 33 \\
\hline March & 23 & 10 & 23 & 13 & 23 & 13 & 21 & 15 & 14 & 18 & 6 & 3 \\
\hline April & 28 & 11 & 26 & 14 & 28 & 16 & 24 & 18 & 3 & 2 & - & - \\
\hline May & 31 & 13 & 29 & 17 & 29 & 19 & 27 & 20 & - & - & - & - \\
\hline
\end{tabular}


Table 4. Amount of supplied water in $\mathrm{m}^{3} \mathrm{fed}^{-1}$ at different barley critical growth stages, rainfall amount and total water supplied at 2014/2015 and 2015/2016 Seasons.

\begin{tabular}{|c|c|c|c|c|c|c|c|c|}
\hline \multirow{3}{*}{ Treatment } & \multirow{3}{*}{$\begin{array}{l}\text { Growth } \\
\text { Season }\end{array}$} & \multicolumn{3}{|c|}{ Growth Stages } & \multicolumn{4}{|c|}{ Irrigation } \\
\hline & & \multirow{2}{*}{$\begin{array}{l}\text { Sowing } \\
\text { irrigation }\end{array}$} & \multirow{2}{*}{$\begin{array}{l}35 \text { days } \\
\text { after } \\
\text { sowing }\end{array}$} & \multirow{2}{*}{$\begin{array}{l}75 \text { days } \\
\text { after } \\
\text { sowing }\end{array}$} & \multirow{2}{*}{$\begin{array}{c}\text { Water } \\
\left(\mathbf{m}^{3}\right)\end{array}$} & \multicolumn{2}{|c|}{ Rainfall } & \multirow{2}{*}{$\begin{array}{r}\text { Total } \\
\left(\mathrm{m}^{3} \text { fed }^{-1}\right)\end{array}$} \\
\hline & & & & & & $\mathbf{m m}$ & $\mathrm{m}^{3} \mathrm{fed}^{-1}$ & \\
\hline Sakha & $2014 / 2015$ & 500 & 350 & 400 & 1250 & 93 & 391 & 1641 \\
\hline normal irrigation & $2015 / 2016$ & 500 & 375 & 425 & 1275 & 52 & 218 & 1493 \\
\hline Sakha & $2014 / 2015$ & 500 & - & - & 550 & 93 & 391 & 941 \\
\hline water stressed & $2015 / 2016$ & 500 & - & - & 500 & 52 & 218 & 718 \\
\hline \multirow{2}{*}{ El-Hosinia } & $2014 / 2015$ & 450 & 350 & 385 & 1185 & 116 & 487 & 1672 \\
\hline & $2015 / 2016$ & 450 & 340 & 370 & 1160 & 84 & 353 & 1513 \\
\hline
\end{tabular}

Stability parameters were computed according to Eberhart and Russell (1966). If regression coefficient $\left(b_{i}\right)$ is significantly larger or smaller than one, the genotype is considered more adapted to favorable and unfavorable environments, respectively with respect to the site mean yield. If $\left(b_{i}\right)$ is not significantly different from one, the genotype is considered stable for all environments. The hypothesis that any regression coefficient does not differ from unity, it was tested by the t-test using its own standard error for regression. The second stability parameter was mean square of the deviation from regression for each genotype. For the regression analysis of variance, the residual from the combined analysis of variance were used as a pooled error to test the $S^{2} d$ values. A significant $F$-value would indicate that the $S^{2} d$ was significantly different from zero. The appropriate analysis of variance is given with this model, the sum of squares due to environments and genotype $\mathrm{x}$ environments (linear) and deviations from the regression model.

\section{Results and Discussion}

\section{Interactions effect:}

The differences among the environments and genotypes were significant for all studied traits, while differences between years were highly significant for all studied traits except for spike length and grain yield fed $^{-1}$ were not significant. Also, the mean square of interaction between the years $\mathrm{x}$ environments, genotypes $\mathrm{x}$ years, genotypes $x$ environments and genotypes $x$ years $x$ environments found to be significant and highly significant for all studied traits (Table 5). These results indicated that, the studied genotypes responded differently to the environmental conditions suggesting the importance of the assessment of genotypes under different environments in order to identify the best genotypes that more adapted for a particular environment.

Table 5. The combined analyses of variance over years (Y), environments (E) and genotypes (G) for all studied traits.

\begin{tabular}{|c|c|c|c|c|c|c|c|c|c|}
\hline SOV & df & $\begin{array}{c}\text { Days to } \\
\text { maturity }\end{array}$ & $\begin{array}{l}\text { Plant } \\
\text { height }\end{array}$ & $\begin{array}{l}\text { Spike } \\
\text { length }\end{array}$ & $\begin{array}{c}\text { No. of } \\
\text { spikes } \mathbf{m}^{-2}\end{array}$ & $\begin{array}{l}\text { No. of } \\
\text { grains } \\
\text { spike }^{-1} \\
\end{array}$ & $\begin{array}{l}\text { Biological } \\
\text { yield }\end{array}$ & $\begin{array}{l}\text { Grain } \\
\text { yield }\end{array}$ & $\begin{array}{c}1000 \\
\text {-grain } \\
\text { weight } \\
\end{array}$ \\
\hline Years (Y) & 1 & $829.6 * *$ & $1806.8 * *$ & $1.3 \mathrm{~ns}$ & $35760.4 * *$ & $3490.7 * *$ & $10443803.5 * *$ & $128332.6 \mathrm{~ns}$ & $116.2^{* *}$ \\
\hline Environments(E) & 2 & $884.1 * *$ & $10308.4 * *$ & $337.4 * *$ & $434033.7 * *$ & $18447.6 * *$ & $233293896.9 * *$ & $17274610.5^{* *}$ & $539.6 * *$ \\
\hline $\mathbf{Y} * \mathbf{E}$ & 2 & $155.2 * *$ & $173.1 * *$ & $78.8 * *$ & $10258.3^{*}$ & $3840.9^{* *}$ & $54094895.7 * *$ & $295903.0 * *$ & $49.5 *$ \\
\hline Error (a) & 9 & 4.4 & 3.5 & 1.4 & 1603.5 & 33.1 & 923590.5 & 28458.9 & 7.8 \\
\hline Genotypes G) & 19 & $94.2 * *$ & $589.1 * *$ & $11.4 * *$ & $9865.1 * *$ & $161.9 * *$ & $3637721.5 * *$ & $172049.5^{* *}$ & $137.9 * *$ \\
\hline $\mathbf{G} * \mathbf{Y}$ & 19 & $8.0 * *$ & $122.8^{* *}$ & $1.6 * *$ & $2838.8 * *$ & $87.2 * *$ & $2140282.4 * *$ & $51897.0 * *$ & $47.2 * *$ \\
\hline $\mathbf{G} * \mathbf{E}$ & 38 & $8.7 * *$ & $64.5^{* *}$ & $0.9^{*}$ & $4060.9 * *$ & $88.3 * *$ & $1371868.7 * *$ & $46697.9 * *$ & $27.1 * *$ \\
\hline $\mathbf{G} * \mathbf{Y} * \mathbf{E}$ & 38 & $6.4 * *$ & $45.9 * *$ & $1.3 * *$ & $2346.7 * *$ & $66.1 * *$ & $1111472.1 * *$ & $18901.9 * *$ & $16.1 * *$ \\
\hline Error (b) & 227 & 2.2 & 3.8 & 0.6 & 1621.3 & 21.1 & 446580.5 & 10010.3 & 4.1 \\
\hline
\end{tabular}

The mean squares due to environments were the most important source of the total mean squares for all characteristics. Also, the variances due to environments were higher than those of interactions between genotypes and environments for all studied characters. Therefore, most of the differences in the performance of barley genotypes in these experiments were due to environment and not to genotype by environment interaction differences. These results are in agreement with those reported by
Mohamed, (2004); Farhat, (2005); El-Shawy, (2008); El-Seidy et al., (2012); El-Seidy et al., (2013); El-Denary and El-Shawy, (2014); Mansour et al., (2016) and El-Shawy et al., (2017).

\section{Environments effect:}

The days required for maturity date were not similar i.e. due to the difference in water applied and/or weather conditions (rainfall and temperature) (Table 3). The average of number of maturity date under water stress condition was reduced by 2.5 days 
compared with normal growth condition (Table 6). Plant height, spike length, No. of spikes $\mathrm{m}^{-2}$, No. of grains spike $^{-1}$, grain yield fed ${ }^{-1}$, biological yield fed ${ }^{-1}$ and 1000-grain weight were reduced under stress treatments compared with normal condition. Results indicated that, the wide range of growth conditions resulted in a broad variation of mean yields, ranging from $7660.7 \mathrm{~kg} \mathrm{fed}^{-1}$ in favorable normal condition to
$4930.5 \mathrm{~kg} \mathrm{fed}^{-1}$ in salinity stress (Table 6). Water stress and salinity stress were considered the major threat to agricultural production, whereas lack of soil moisture and soil salinity restricts plant growth. Limitation of growth resources by stresses, reduce the size of plant organs such as leaves, tillers, and spikes (Fischer 1984).

Table 6. Means of the twenty genotypes over years and environments.

\begin{tabular}{|c|c|c|c|c|c|c|c|c|}
\hline Item & $\begin{array}{l}\text { Days to } \\
\text { maturity }\end{array}$ & $\begin{array}{c}\text { Plant } \\
\text { height } \\
\text { (cm) }\end{array}$ & $\begin{array}{c}\text { Spike } \\
\text { length } \\
(\mathrm{cm})\end{array}$ & $\begin{array}{c}\text { No. of } \\
\text { spikes } \\
\text { m }^{-2}\end{array}$ & $\begin{array}{c}\text { No. of } \\
\text { grains } \\
\text { spike }^{-1}\end{array}$ & $\begin{array}{c}\text { Biological } \\
\text { Yield } \\
\left(\mathrm{kg} \mathrm{fed}^{-1}\right)\end{array}$ & $\begin{array}{c}\text { Grain } \\
\text { yield } \\
\left(\mathrm{kg} \mathrm{fed}^{-1}\right)\end{array}$ & $\begin{array}{c}1000 \\
\text {-grain } \\
\text { weight }(\mathrm{g})\end{array}$ \\
\hline First year & 127.0 & 92.7 & 8.0 & 332.9 & 63.1 & 6435.3 & 2517.3 & 50.9 \\
\hline Second year & 130.1 & 97.2 & 8.2 & 352.8 & 56.9 & 6122.5 & 2596.6 & 49.8 \\
\hline Normal & 128.4 & 104.7 & 9.7 & 402.0 & 73.1 & 7660.7 & 3233.7 & 52.2 \\
\hline Water stress & 125.9 & 93.9 & 8.2 & 344.9 & 58.4 & 6245.6 & 2758.3 & 50.8 \\
\hline Salinity stress & 131.3 & 86.2 & 6.4 & 281.8 & 48.5 & 4930.5 & 1678.8 & 48.0 \\
\hline Mean overall & 128.54 & 94.9 & 8.1 & 342.9 & 60.0 & 6278.91 & 2556.94 & 50.33 \\
\hline LSD at 0.05 & 3.86 & 3.5 & 2.2 & 74.0 & 10.6 & 1822.22 & 654.30 & 1.05 \\
\hline
\end{tabular}

Performance of genotypes:

The mean number of days to maturity for different genotypes ranged from 124.1 for Line 1 to 132 days for Line 6 . The earliest genotypes were Line 1 and Line 2, whereas Giza 132, Line 5 and Line 6 were the latest genotypes (Table 7). The average of plant height ranged from $86.7 \mathrm{~cm}$ for Line 9 (the shortest genotype) to $106.3 \mathrm{~cm}$ for Line 7 (the tallest genotype) (Table 8). Giza 132, Line 3, Line 5 and Line 7 gave the highest values for plant height in both seasons. The tallest plant was achieved when plants were grown under the normal conditions compared with those plants grown under the stress treatments. The reduction in plant height could be attributed to lower crop growth rate and the decrease in relative water content. These results are in harmony with those of Nabipour et al., (2002), Bayoumi (2004), Mohamed (2004), Farhat (2005), Bagheri and abad (2007), Samarah et al., (2009) and Vaezi et al., (2010).

Table 7. Means of days to maturity for the 20 studied genotypes under normal (N), water stress (WS) and saline soil (Sal) during 2014/2015 and 2015/2016 seasons.

\begin{tabular}{lccccccc}
\hline \multirow{2}{*}{ Genotype } & $\mathbf{N}$ & $\mathbf{W S}$ & Sal & $\mathbf{N}$ & $\mathbf{W S}$ & Sal & Mean \\
\cline { 2 - 6 } & 124.7 & 121.0 & 129.0 & 128.0 & 125.3 & 129.3 & 126.2 \\
Giza 123 & 126.0 & 125.3 & 133.7 & 131.0 & 129.0 & 133.3 & 129.7 \\
Giza 126 & 128.3 & 127.3 & 135.3 & 133.3 & 129.7 & 133.7 & 131.3 \\
Giza 132 & 123.7 & 121.0 & 133.3 & 128.0 & 126.0 & 130.0 & 127.0 \\
Giza 133 & 126.0 & 124.3 & 131.3 & 132.0 & 128.7 & 133.7 & 129.3 \\
Giza 134 & 127.0 & 120.7 & 126.3 & 126.3 & 127.0 & 128.7 & 126.0 \\
Giza 129 & 127.0 & 127.0 & 127.3 & 133.3 & 129.3 & 133.7 & 129.6 \\
Giza 130 & 125.7 & 127.3 & 133.3 & 132.7 & 129.7 & 132.0 & 130.1 \\
Giza 131 & 127.3 & 126.7 & 131.7 & 132.0 & 129.0 & 129.0 & 129.3 \\
Giza 135 & 130.0 & 126.7 & 135.3 & 132.0 & 129.0 & 133.3 & 131.1 \\
Giza 136 & 122.3 & 118.7 & 125.0 & 127.0 & 125.7 & 126.0 & 124.1 \\
Line 1 & 122.7 & 120.0 & 126.0 & 127.0 & 125.3 & 125.3 & 124.4 \\
Line 2 & 126.3 & 120.7 & 127.3 & 130.3 & 127.7 & 132.0 & 127.4 \\
Line 3 & 125.7 & 122.7 & 129.0 & 132.0 & 127.7 & 129.0 & 127.7 \\
Line 4 & 127.0 & 128.0 & 135.3 & 133.3 & 130.7 & 135.0 & 131.6 \\
Line 5 & 128.0 & 128.7 & 135.7 & 134.3 & 129.7 & 135.7 & 132.0 \\
Line 6 & 123.7 & 121.0 & 129.3 & 129.0 & 126.7 & 132.7 & 127.1 \\
Line 7 & 129.0 & 126.0 & 132.7 & 131.3 & 128.7 & 133.3 & 130.2 \\
Line 8 & 126.3 & 121.7 & 136.5 & 129.7 & 126.3 & 132.7 & 128.9 \\
Line 9 & 125.0 & 122.7 & 129.0 & 130.7 & 128.3 & 132.7 & 128.1 \\
Line 10 & $\mathbf{2 . 1}$ & $\mathbf{1 . 9}$ & $\mathbf{4 . 0}$ & $\mathbf{2 . 0}$ & $\mathbf{1 . 6}$ & $\mathbf{2 . 3}$ & $\mathbf{2 . 4}$ \\
\hline LSD at 0.05 & & & & & & & \\
\hline & & & & & & & \\
\end{tabular}


Table 8. Means of plant height $(\mathrm{cm})$ for the 20 studied genotypes under normal $(\mathrm{N})$, water stress (WS) and saline soil (Sal) during 2014/2015 and 2015/2016 seasons.

\begin{tabular}{|c|c|c|c|c|c|c|c|}
\hline \multirow{2}{*}{ Genotype } & \multicolumn{3}{|c|}{$2014 / 2015$} & \multicolumn{3}{|c|}{$2015 / 2016$} & \multirow{2}{*}{ Mean } \\
\hline & $\mathbf{N}$ & WS & Sal & $\mathbf{N}$ & WS & Sal & \\
\hline Giza 123 & 106.3 & 86.0 & 90.4 & 110.3 & 86.7 & 84.3 & 94.0 \\
\hline Giza 126 & 106.3 & 95.0 & 91.7 & 112.0 & 90.3 & 85.0 & 96.7 \\
\hline Giza 132 & 112.0 & 98.7 & 92.9 & 119.3 & 105.3 & 95.3 & 103.9 \\
\hline Giza 133 & 96.7 & 91.0 & 79.6 & 95.0 & 91.0 & 78.0 & 88.5 \\
\hline Giza 134 & 101.3 & 94.0 & 86.1 & 111.7 & 103.7 & 92.3 & 98.2 \\
\hline Giza 129 & 95.0 & 90.0 & 78.8 & 103.0 & 89.3 & 87.0 & 90.5 \\
\hline Giza 130 & 92.7 & 80.3 & 75.7 & 111.3 & 91.3 & 94.0 & 90.9 \\
\hline Giza 131 & 97.3 & 91.0 & 75.1 & 105.3 & 100.3 & 93.3 & 93.7 \\
\hline Giza 135 & 96.7 & 92.0 & 77.9 & 99.7 & 91.7 & 86.3 & 90.7 \\
\hline Giza 136 & 103.3 & 79.7 & 87.8 & 110.3 & 100.0 & 95.3 & 96.1 \\
\hline Line 1 & 92.7 & 90.3 & 78.8 & 102.3 & 89.3 & 87.3 & 90.1 \\
\hline Line 2 & 99.0 & 98.0 & 84.2 & 106.7 & 100.3 & 85.7 & 95.6 \\
\hline Line 3 & 113.7 & 98.0 & 96.6 & 103.3 & 99.3 & 90.7 & 100.3 \\
\hline Line 4 & 99.7 & 96.3 & 84.7 & 116.7 & 103.3 & 83.7 & 97.4 \\
\hline Line 5 & 112.0 & 106.7 & 95.2 & 118.0 & 109.0 & 94.0 & 105.8 \\
\hline Line 6 & 96.3 & 93.3 & 81.9 & 103.7 & 94.0 & 87.0 & 92.7 \\
\hline Line 7 & 115.0 & 112.0 & 95.2 & 115.7 & 105.0 & 95.0 & 106.3 \\
\hline Line 8 & 98.7 & 87.7 & 83.9 & 109.0 & 86.3 & 83.3 & 91.5 \\
\hline Line 9 & 93.7 & 75.3 & 79.6 & 110.3 & 88.3 & 72.7 & 86.7 \\
\hline Line 10 & 92.3 & 90.7 & 78.5 & 102.0 & 86.0 & 83.3 & 88.8 \\
\hline LSD at 0.05 & 3.2 & 3.0 & 2.6 & 4.1 & 2.7 & 3.3 & 3.2 \\
\hline
\end{tabular}

For spike length means of the twenty barley genotypes, showed highly significant differences between barley genotypes (Table 9). Giza 131 and
Line 6 gave the highest values for spike length, while the lowest value obtained from Giza 133 (compacted spike type).

Table 9. Means of spike length (cm) for the 20 studied genotypes under normal (N), water stress (WS) and saline soil (Sal) during 2014/2015 and 2015/2016 seasons.

\begin{tabular}{cccccccc}
\hline \multirow{2}{*}{ Genotype } & \multicolumn{2}{c}{$\mathbf{2 0 1 4 / 2 0 1 5}$} & & & $\mathbf{2 0 1 5 / 2 0 1 6}$ & \multirow{2}{*}{ Mean } \\
\cline { 2 - 6 } Giza 123 & $\mathbf{N}$ & $\mathbf{\text { WS }}$ & Sal & $\mathbf{N}$ & WS & Sal & \\
Giza 126 & 7.7 & 8.0 & 5.7 & 10.0 & 7.3 & 7.3 & 7.8 \\
Giza 132 & 11.7 & 10.3 & 4.3 & 8.7 & 7.0 & 6.0 & 7.0 \\
Giza 133 & 7.7 & 7.7 & 6.0 & 10.0 & 7.7 & 7.3 & 8.8 \\
Giza 134 & 8.7 & 9.0 & 5.7 & 7.7 & 5.0 & 4.7 & 6.1 \\
Giza 129 & 9.7 & 9.7 & 7.0 & 9.3 & 6.0 & 7.3 & 7.6 \\
Giza 130 & 9.7 & 9.0 & 5.3 & 11.0 & 8.0 & 8.3 & 8.9 \\
Giza 131 & 10.3 & 10.7 & 7.0 & 11.3 & 8.7 & 7.7 & 8.6 \\
Giza 135 & 9.7 & 7.7 & 5.7 & 9.3 & 7.7 & 8.7 & 9.4 \\
Giza 136 & 10.3 & 9.3 & 7.7 & 10.3 & 7.7 & 7.7 & 7.7 \\
Line 1 & 10.3 & 8.7 & 5.7 & 9.7 & 8.0 & 7.7 & 8.8 \\
Line 2 & 11.0 & 8.3 & 5.7 & 10.7 & 7.7 & 7.0 & 8.4 \\
Line 3 & 9.7 & 9.7 & 4.5 & 11.0 & 7.0 & 7.3 & 8.2 \\
Line 4 & 10.0 & 9.3 & 6.5 & 9.0 & 7.3 & 7.7 & 8.3 \\
Line 5 & 10.3 & 9.0 & 5.3 & 9.0 & 7.7 & 6.7 & 8.0 \\
Line 6 & 11.0 & 9.7 & 6.3 & 11.0 & 8.3 & 7.7 & 9.0 \\
Line 7 & 10.7 & 9.3 & 6.3 & 10.3 & 7.0 & 7.3 & 8.5 \\
Line 8 & 8.7 & 7.3 & 4.7 & 8.3 & 7.7 & 6.0 & 7.1 \\
Line 9 & 8.3 & 9.0 & 4.5 & 9.7 & 6.7 & 7.7 & 7.6 \\
Line 10 & 8.3 & 9.0 & 4.5 & 10.7 & 7.0 & 7.3 & 7.8 \\
\hline LSD at 0.05 & $\mathbf{1 . 1}$ & $\mathbf{1 . 2}$ & $\mathbf{1 . 5}$ & $\mathbf{1 . 6}$ & $\mathbf{1 . 0}$ & $\mathbf{0 . 8}$ & $\mathbf{1 . 2}$ \\
\hline
\end{tabular}


For mean number of spike $\mathrm{m}^{-2}$, Giza 133 , Giza 134, Line 5, Line 6 and Line 7 gave the highest values $(389.1,374.4,385.7,363.6$ and 369.3 spikes), respectively. Whereas Giza 136 (314.6) and Line 2 (313.1) were the lowest genotypes (Table 10). Giza 133, Giza 134 and Line 7 were superiors under saline conditions in both growing seasons. The normal condition recorded the highest number of spike $\mathrm{m}^{-2}$. The severe water stress and saline treatments decreased spike number in both growing seasons. Such response may be attributed to lack of water absorbed and reduction in photosynthetic efficiency under insufficient water condition. Moreover, the reduction in assimilates translocated to new developing tillers might owe much the death of the new tillers and depressed the number of spikes primordial. These results are confirmed byAbd ElWahab (2002), Bayoumi (2004), Mohamed (2004), Farhat (2005), Mahmoud (2006), Bagheri and abad (2007), Samarah et al., (2009) and Vaezi et al., (2010).

Table 10. Means of no. of spikes $\mathrm{m}^{-2}$ for the 20 studied genotypes under normal (N), water stress (WS) and saline soil (Sal) during 2014/2015 and 2015/2016 seasons.

\begin{tabular}{|c|c|c|c|c|c|c|c|}
\hline \multirow{2}{*}{ Genotype } & \multicolumn{3}{|c|}{$2014 / 2015$} & \multicolumn{3}{|c|}{$2015 / 2016$} & \multirow{2}{*}{ Mean } \\
\hline & $\mathbf{N}$ & WS & Sal & $\mathbf{N}$ & WS & Sal & \\
\hline Giza 123 & 430.0 & 356.0 & 306.7 & 436.0 & 328.0 & 294.7 & 358.6 \\
\hline Giza 126 & 364.0 & 344.0 & 241.7 & 414.0 & 340.0 & 313.3 & 336.2 \\
\hline Giza 132 & 354.0 & 336.0 & 218.3 & 386.0 & 332.0 & 326.7 & 325.5 \\
\hline Giza 133 & 390.0 & 371.3 & 343.3 & 456.0 & 414.0 & 360.0 & 389.1 \\
\hline Giza 134 & 392.0 & 374.0 & 328.3 & 432.0 & 384.0 & 336.0 & 374.4 \\
\hline Giza 129 & 390.0 & 294.0 & 250.0 & 380.0 & 312.0 & 317.3 & 323.9 \\
\hline Giza 130 & 342.0 & 288.0 & 300.0 & 370.0 & 308.0 & 308.0 & 319.3 \\
\hline Giza 131 & 412.0 & 344.0 & 286.7 & 322.0 & 280.0 & 294.7 & 323.2 \\
\hline Giza 135 & 374.0 & 366.0 & 225.0 & 400.0 & 340.0 & 297.3 & 333.7 \\
\hline Giza 136 & 382.0 & 290.0 & 245.0 & 388.0 & 316.0 & 266.7 & 314.6 \\
\hline Line 1 & 374.0 & 392.0 & 231.7 & 454.0 & 354.0 & 282.7 & 348.1 \\
\hline Line 2 & 360.0 & 298.0 & 228.3 & 420.0 & 308.0 & 264.0 & 313.1 \\
\hline Line 3 & 444.0 & 432.0 & 166.7 & 446.0 & 370.0 & 254.3 & 352.2 \\
\hline Line 4 & 364.0 & 294.0 & 295.0 & 406.0 & 344.0 & 270.7 & 328.9 \\
\hline Line 5 & 424.0 & 424.0 & 288.3 & 450.0 & 416.0 & 312.0 & 385.7 \\
\hline Line 6 & 392.0 & 368.7 & 283.3 & 420.0 & 400.0 & 317.3 & 363.6 \\
\hline Line 7 & 450.0 & 404.0 & 293.3 & 426.0 & 308.0 & 334.7 & 369.3 \\
\hline Line 8 & 352.0 & 330.0 & 226.7 & 432.0 & 328.0 & 332.0 & 333.4 \\
\hline Line 9 & 384.0 & 282.0 & 265.0 & 416.0 & 374.0 & 248.0 & 328.2 \\
\hline Line 10 & 436.0 & 308.0 & 245.0 & 416.0 & 342.0 & 272.0 & 336.5 \\
\hline LSD at 0.05 & 42.6 & 60.5 & 90.5 & 57.1 & 83.4 & 49.9 & 65.6 \\
\hline
\end{tabular}

Concerning response of grains number/spike, the differences among genotypes were highly significant in both growing seasons, indicating overall differences between growth conditions. Giza132 (64.4 grains), Giza 130 (64.0 grains), Giza 131 (64.7 grains) and Line 7 (63.3 grains) produced the highest mean number of grains/spike (Table 11). The reduction might be due to the reduction in photosynthetic efficiency and the lack of photosynthates translocated to the developing seeds by adding irrigation might owe much to these results. According to Ceccarelli (1987), water deficit during the early stage of plant development induces a reduction in spikelets primordia, while water deficit late in the plant development increases death of the flower and the entire spikelet. The number of grains spike $^{-1}$ (fertility) depends on water availability during the early vegetative phase and during shooting stage. If water deficit occurs after the flowering stage, it induces a decrease of grain weight and thus its yield.
The results are supported with obtained by Mohamed (2004), Farhat (2005), Bagheri and abad (2007), Samarah et al., (2009) and Vaezi et al., (2010).

Results in Table $\mathbf{1 2}$ show that genotypes exhibited highly significant differences in biological yield $\mathrm{fed}^{-1}$. Line 6 and Line 7 gave the highest mean values $(6885.6$ and $7178.9 \mathrm{~kg})$, respectively. Whereas, Giza 129 (5093.1 kg) and Line 9 (5609 kg) were the lowest genotypes. Grain yield $\mathrm{fed}^{-1}$ mean of the genotypes ranged from 2128.8 to $2943.7 \mathrm{~kg} \mathrm{fed}^{-1}$ for Giza 129 and Line 7, respectively, with an overall average of $2556.9 \mathrm{~kg} \mathrm{fed}^{-1}$ (Table 13). The best genotype was Giza 133, Giza 134, Line 3, Line 6 and Line 7 under the normal condition, while Giza 134, Line 6 and Line 7 were superior under water stress conditions. Under saline condition Giza 133, Giza 134 and Line 7 had good performance in both growing seasons in addition to Giza 126 in the second season. For 1000-grain weight mean, Giza 
123, Giza 136 Line 4, and Line 7 gave the highest mean values $(54.2,54.1,54.0$ and $54.3 \mathrm{~g})$, respectively. Whereas, Giza 129 (44.9 g) and Giza 135 (45.0 g) had the lowest mean values (Table 14).

Table 11. Means of no. of grains spike ${ }^{-1}$ for the 20 studied genotypes under normal (N), water stress (WS) and saline soil (Sal) during 2014/2015 and 2015/2016 seasons.

\begin{tabular}{|c|c|c|c|c|c|c|c|}
\hline \multirow{2}{*}{ Genotype } & \multicolumn{3}{|c|}{$2014 / 2015$} & \multicolumn{3}{|c|}{$2015 / 2016$} & \multirow{2}{*}{ Mean } \\
\hline & $\mathbf{N}$ & WS & Sal & $\mathbf{N}$ & WS & Sal & \\
\hline Giza 123 & 62.0 & 58.0 & 46.0 & 70.0 & 50.0 & 50.0 & 56.0 \\
\hline Giza 126 & 76.0 & 68.0 & 44.0 & 52.0 & 54.0 & 48.0 & 57.0 \\
\hline Giza 132 & 84.0 & 78.7 & 48.0 & 72.0 & 52.0 & 52.0 & 64.4 \\
\hline Giza 133 & 73.0 & 69.3 & 38.0 & 56.0 & 46.7 & 46.7 & 54.9 \\
\hline Giza 134 & 74.0 & 68.0 & 44.0 & 68.0 & 47.3 & 52.0 & 58.9 \\
\hline Giza 129 & 76.0 & 68.0 & 54.0 & 70.0 & 50.0 & 54.0 & 62.0 \\
\hline Giza 130 & 74.0 & 68.0 & 44.0 & 84.0 & 60.0 & 54.0 & 64.0 \\
\hline Giza 131 & 74.0 & 68.0 & 54.0 & 76.0 & 56.0 & 60.0 & 64.7 \\
\hline Giza 135 & 82.0 & 52.0 & 46.0 & 72.0 & 50.0 & 52.0 & 59.0 \\
\hline Giza 136 & 74.0 & 62.0 & 58.0 & 66.0 & 46.0 & 48.0 & 59.0 \\
\hline Line 1 & 84.0 & 70.0 & 44.0 & 76.0 & 48.0 & 52.0 & 62.3 \\
\hline Line 2 & 80.0 & 62.0 & 48.0 & 72.0 & 46.0 & 48.0 & 59.3 \\
\hline Line 3 & 76.0 & 72.0 & 42.0 & 80.0 & 42.0 & 52.0 & 60.7 \\
\hline Line 4 & 76.0 & 68.0 & 51.0 & 68.0 & 44.0 & 54.0 & 60.2 \\
\hline Line 5 & 74.0 & 68.0 & 44.0 & 60.0 & 46.0 & 46.0 & 56.3 \\
\hline Line 6 & 78.0 & 74.0 & 53.3 & 76.0 & 50.0 & 54.0 & 64.2 \\
\hline Line 7 & 76.0 & 72.0 & 54.0 & 76.0 & 52.0 & 58.0 & 64.7 \\
\hline Line 8 & 74.0 & 68.0 & 42.0 & 62.0 & 54.0 & 48.0 & 58.0 \\
\hline Line 9 & 74.0 & 66.0 & 42.0 & 78.0 & 44.0 & 42.7 & 57.8 \\
\hline Line 10 & 74.0 & 68.0 & 39.0 & 76.0 & 50.0 & 44.0 & 58.5 \\
\hline LSD at 0.05 & 6.7 & 5.6 & 9.3 & 9.6 & 5.8 & 6.6 & 7.38 \\
\hline
\end{tabular}

Table 12. Means of biological yield $\left(\mathrm{kg} \mathrm{fed}^{-1}\right)$ for the 20 studied genotypes under normal (N), water stress (WS) and saline soil (Sal) during 2014/2015 and 2015/2016 seasons.

\begin{tabular}{|c|c|c|c|c|c|c|c|}
\hline \multirow{2}{*}{ Genotype } & \multicolumn{3}{|c|}{$2014 / 2015$} & \multicolumn{3}{|c|}{$2015 / 2016$} & \multirow{2}{*}{ Mean } \\
\hline & $\mathbf{N}$ & WS & Sal & $\mathbf{N}$ & WS & Sal & \\
\hline Giza 123 & 8143.3 & 7002.9 & 3777.7 & 7024.7 & 5894.6 & 5618.5 & 6243.6 \\
\hline Giza 126 & 8400.0 & 7298.7 & 3698.3 & 7838.4 & 5736.3 & 5913.6 & 6480.9 \\
\hline Giza 132 & 8509.7 & 7099.0 & 3672.2 & 9152.0 & 6046.1 & 5457.5 & 6656.1 \\
\hline Giza 133 & 8474.7 & 7614.3 & 4055.3 & 5291.8 & 5138.4 & 6032.5 & 6156.7 \\
\hline Giza 134 & 8424.8 & 6641.3 & 5137.2 & 8118.3 & 5759.0 & 5899.9 & 6552.3 \\
\hline Giza 129 & 6517.2 & 4982.3 & 4063.5 & 5325.3 & 4574.2 & 5096.0 & 5093.1 \\
\hline Giza 130 & 7770.0 & 7612.5 & 4678.7 & 8414.1 & 4687.9 & 5292.0 & 6409.2 \\
\hline Giza 131 & 8572.3 & 7356.3 & 4018.0 & 7566.1 & 4770.3 & 4996.4 & 6213.2 \\
\hline Giza 135 & 7095.5 & 6715.2 & 3491.6 & 7557.7 & 4654.6 & 4754.2 & 5711.5 \\
\hline Giza 136 & 6958.0 & 6928.5 & 4092.0 & 7489.1 & 5805.5 & 5236.0 & 6084.9 \\
\hline Line 1 & 7096.9 & 6265.8 & 4198.3 & 7588.4 & 7290.5 & 6002.5 & 6407.1 \\
\hline Line 2 & 7540.3 & 7236.3 & 4922.4 & 6593.2 & 5978.9 & 4400.2 & 6111.9 \\
\hline Line 3 & 8591.7 & 6994.6 & 3128.4 & 8745.3 & 6072.7 & 5796.7 & 6554.9 \\
\hline Line 4 & 7202.5 & 6289.4 & 5578.7 & 6472.0 & 5328.0 & 5757.5 & 6104.7 \\
\hline Line 5 & 7918.7 & 6758.2 & 5023.0 & 7376.6 & 5061.8 & 5603.4 & 6290.3 \\
\hline Line 6 & 9037.7 & 7570.7 & 5426.4 & 7492.3 & 6459.3 & 5327.1 & 6885.6 \\
\hline Line 7 & 10042.7 & 8808.7 & 5047.0 & 6895.0 & 6163.5 & 6116.3 & 7178.9 \\
\hline Line 8 & 9229.2 & 6021.9 & 4557.0 & 7270.8 & 5250.0 & 5198.2 & 6254.5 \\
\hline Line 9 & 6760.0 & 6260.1 & 3513.3 & 6973.4 & 5040.0 & 5105.9 & 5608.8 \\
\hline Line 10 & 8222.7 & 7917.5 & 4160.1 & 6734.0 & 4739.0 & 5374.9 & 6191.4 \\
\hline LSD at 0.05 & 1310.6 & 993.1 & 1409.9 & 1182.3 & 973.6 & 557.2 & 1089.1 \\
\hline
\end{tabular}


Table 13. Means of grain yield $\left(\mathrm{kg} \mathrm{fed}^{-1}\right)$ for the 20 studied genotypes under normal (N), water stress (WS) and saline soil (Sal) during 2014/2015 and 2015/2016 seasons.

\begin{tabular}{|c|c|c|c|c|c|c|c|}
\hline \multirow{2}{*}{ Genotype } & \multicolumn{3}{|c|}{$2014 / 2015$} & \multicolumn{3}{|c|}{$2015 / 2016$} & \multirow{2}{*}{ Mean } \\
\hline & $\mathbf{N}$ & WS & Sal & $\mathbf{N}$ & WS & Sal & \\
\hline Giza 123 & 2998.3 & 2916.7 & 1448.0 & 3252.7 & 2695.6 & 1957.6 & 2544.8 \\
\hline Giza 126 & 3066.0 & 3009.1 & 1480.0 & 3128.6 & 2834.1 & 2066.4 & 2597.4 \\
\hline Giza 132 & 3054.3 & 2889.8 & 1225.0 & 3544.0 & 2804.7 & 1634.3 & 2525.4 \\
\hline Giza 133 & 3355.3 & 3166.9 & 1812.8 & 3383.0 & 2925.5 & 1939.4 & 2763.8 \\
\hline Giza 134 & 3474.2 & 3238.7 & 2081.5 & 3438.8 & 2942.5 & 1812.1 & 2831.3 \\
\hline Giza 129 & 2538.8 & 2168.3 & 1260.0 & 3115.9 & 2201.4 & 1488.4 & 2128.8 \\
\hline Giza 130 & 2858.3 & 2712.5 & 1763.3 & 3080.0 & 2379.3 & 1627.5 & 2403.5 \\
\hline Giza 131 & 3090.1 & 2889.2 & 1732.5 & 3319.3 & 2414.8 & 1743.5 & 2531.6 \\
\hline Giza 135 & 3053.0 & 2254.0 & 1259.0 & 3198.8 & 2192.0 & 1270.1 & 2204.5 \\
\hline Giza 136 & 3150.0 & 2667.0 & 1620.0 & 3303.1 & 2793.8 & 1832.9 & 2561.1 \\
\hline Line 1 & 3090.7 & 2959.9 & 1596.8 & 3435.3 & 3125.3 & 2009.0 & 2702.8 \\
\hline Line 2 & 3073.8 & 3080.7 & 1757.0 & 3133.3 & 2441.6 & 1498.9 & 2497.5 \\
\hline Line 3 & 3458.3 & 3069.3 & 892.5 & 3677.3 & 2938.7 & 1652.0 & 2614.7 \\
\hline Line 4 & 2932.9 & 2747.7 & 1754.7 & 2990.0 & 2686.6 & 1657.6 & 2461.6 \\
\hline Line 5 & 3153.1 & 2683.7 & 1488.0 & 2865.3 & 2559.3 & 2100.0 & 2474.9 \\
\hline Line 6 & 3937.3 & 3325.3 & 1670.7 & 3664.1 & 3185.3 & 1646.3 & 2904.8 \\
\hline Line 7 & 4006.3 & 3467.9 & 1820.0 & 3365.7 & 3031.0 & 1971.2 & 2943.7 \\
\hline Line 8 & 3251.2 & 2346.3 & 1610.0 & 3316.9 & 2681.0 & 2324.0 & 2588.2 \\
\hline Line 9 & 2873.1 & 2350.0 & 1300.0 & 3353.0 & 2625.0 & 2126.1 & 2437.9 \\
\hline Line 10 & 3077.5 & 2683.3 & 1347.0 & 3290.0 & 2249.6 & 1876.0 & 2420.6 \\
\hline LSD at 0.05 & 402.6 & 344.0 & 337.6 & 283.8 & 376.6 & 318.4 & 342.4 \\
\hline
\end{tabular}

Table 14. Means of 1000-grain weight (g) for the 20 studied genotypes under normal (N), water stress (WS) and saline soil (Sal) during 2014/2015 and 2015/2016 seasons.

\begin{tabular}{cccccccc}
\hline \multirow{2}{*}{ Genotype } & \multicolumn{2}{c}{$\mathbf{2 0 1 4 / 2 0 1 5}$} & & & $\mathbf{2 0 1 5 / 2 0 1 6}$ & \multirow{2}{*}{ Mean } \\
\cline { 2 - 6 } Giza 123 & $\mathbf{N}$ & $\mathbf{W S}$ & Sal & $\mathbf{N}$ & $\mathbf{W S}$ & Sal & 54.2 \\
Giza 126 & 53.1 & 53.4 & 49.7 & 57.7 & 55.1 & 56.0 & 50.2 \\
Giza 132 & 51.7 & 55.1 & 45.1 & 51.4 & 50.5 & 49.0 & 49.1 \\
Giza 133 & 53.7 & 46.5 & 44.3 & 57.3 & 52.6 & 42.4 & 52.9 \\
Giza 134 & 54.0 & 54.0 & 52.0 & 53.6 & 51.6 & 52.5 & 52.0 \\
Giza 129 & 49.7 & 44.8 & 49.1 & 54.6 & 53.1 & 46.2 & 44.9 \\
Giza 130 & 53.2 & 51.3 & 43.7 & 47.5 & 42.4 & 41.2 & 48.8 \\
Giza 131 & 50.0 & 49.9 & 49.5 & 46.3 & 53.0 & 46.0 & 49.1 \\
Giza 135 & 49.9 & 44.3 & 43.9 & 45.8 & 43.8 & 42.2 & 45.0 \\
Giza 136 & 56.4 & 55.2 & 52.4 & 55.5 & 54.9 & 50.0 & 54.1 \\
Line 1 & 56.5 & 52.7 & 47.6 & 50.7 & 52.3 & 52.0 & 52.0 \\
Line 2 & 50.7 & 47.1 & 49.6 & 56.8 & 55.9 & 56.6 & 52.8 \\
Line 3 & 53.7 & 52.2 & 49.8 & 50.4 & 54.4 & 43.1 & 50.6 \\
Line 4 & 56.8 & 54.9 & 45.5 & 59.9 & 56.0 & 50.8 & 54.0 \\
Line 5 & 51.5 & 49.1 & 47.6 & 52.7 & 49.8 & 51.4 & 50.4 \\
Line 6 & 51.6 & 50.1 & 50.0 & 53.6 & 54.0 & 43.0 & 50.4 \\
Line 7 & 57.7 & 56.2 & 49.9 & 57.3 & 56.8 & 47.9 & 54.3 \\
Line 8 & 50.1 & 46.1 & 46.0 & 55.8 & 54.1 & 56.9 & 51.5 \\
Line 9 & 58.9 & 56.1 & 51.7 & 58.1 & 51.0 & 44.9 & 53.5 \\
Line 10 & 55.8 & 54.4 & 43.1 & 52.2 & 50.8 & 42.6 & 49.8 \\
\hline LSD at 0.05 & $\mathbf{5 . 4}$ & $\mathbf{3 . 8}$ & $\mathbf{8 . 4}$ & $\mathbf{3 . 0}$ & $\mathbf{3 . 4}$ & $\mathbf{4 . 1}$ & $\mathbf{5 . 0}$ \\
\hline
\end{tabular}

The stability regression coefficient $\left(b_{i}\right)$ and deviation from regression $\left(\mathrm{S}^{2} \mathrm{~d}\right)$ for the studied genotypes are presented in Table 15. A stable genotype is one with a high mean performance, unit regression coefficient $\left(b_{i}=1\right)$ and deviation from regression equal to zero (Awad, 1997). The predictability of genotypes for the yield ranged from 0.79 for Line 5 , to 1.52 for Line 3 (Table 15). Based 
on regression coefficient (bi) values the tested genotypes divided into three groups. The first group included the most stable genotypes, Giza 123, Giza 126, Giza 133, Giza 134, Giza 129, Giza 131, Giza 135, Giza 136, Line 1, Line 2, Line 7, Line 9 and Line 10 with coefficient of regression $b_{i}$ values equal to 1 . The second group included the more adapted genotypes to unfavorable environments, Giza 130, Line 4, Line 5 and Line 8 (had the lowest $b_{i}$ values), whereas genotypes Giza 132, Line 3 and Line 6 were input sensitive and adapted to high potential environments. This is similar to the report of Gebremedhin (2015), Elakhdar et al., (2017) and Mansour et al., (2018).

Table 15. Means of 20 studied genotypes and stability parameters, coefficient of regression $\left(b_{i}\right)$ and deviation from regression $\left(\mathrm{S}^{2} \mathrm{~d}\right)$ for grain yield.

\begin{tabular}{cccc}
\hline Genotype & Mean $\left(\mathbf{K g ~ f e d ~}^{-\mathbf{1}}\right)$ & $\mathbf{b}_{\mathbf{i}}$ & $\mathbf{S}_{\mathbf{d}}^{\mathbf{2}}$ \\
\hline Giza 123 & 2544.8 & 0.95 & 322.91 \\
Giza 126 & 2597.4 & 0.91 & 3998.22 \\
Giza 132 & 2525.4 & $1.23 * *$ & 1532.73 \\
Giza 133 & 2763.8 & 0.98 & -1037.50 \\
Giza 134 & 2831.3 & 0.96 & 6536.83 \\
Giza 129 & 2128.8 & 0.91 & 6551.20 \\
Giza 130 & 2403.5 & 0.80 & 2009.71 \\
Giza 131 & 2531.6 & 0.93 & 2692.39 \\
Giza 135 & 2204.5 & 1.13 & 7413.42 \\
Giza 136 & 2561.1 & 0.95 & -1122.93 \\
Line 1 & 2702.8 & 0.98 & 5169.68 \\
Line 2 & 2497.5 & 0.95 & 12134.35 \\
Line 3 & 2614.7 & $1.52 * *$ & 1980.60 \\
Line 4 & 2461.6 & 0.81 & 1018.88 \\
Line 5 & 2474.9 & 0.79 & 5425.42 \\
Line 6 & 2904.8 & $1.36 * *$ & 7391.54 \\
Line 7 & 2943.7 & 1.05 & 1441.25 \\
Line 8 & 2588.2 & 0.80 & 19352.82 \\
Line 9 & 2437.9 & 0.90 & 17998.43 \\
Line 10 & 2420.6 & 0.99 & 5372.13 \\
\hline
\end{tabular}

Giza 133 and Line 7 had desired performance (grain yield) compared to the grand mean, regression coefficient (bi) did not differ significantly from unity and had low deviation from regression $\left(\mathrm{S}^{2} \mathrm{~d}\right)$ values, indicating the role of linear portion of $G \times E$ interaction in the performance of this genotype.

Cluster analysis based on environments mean yield during 2014/2015 and 2015/2016 seasons were performed (Fig. 1). In this analysis two main clusters were appeared. The first main cluster contained Line 6, Line 7, Giza 133 and Giza134 the most desired grain yield $\mathrm{fed}^{-1}$ performance. The rest genotypes were found in the second main cluster. Giza 129 and Giza 135 the lowest mean grain yield fed $^{-1}$ genotypes were found together in the same sub-cluster. Cluster analysis has been used for description of the diversity based on similar characteristics Subhani et al., (2015) and Mariey and Khedr (2017). 


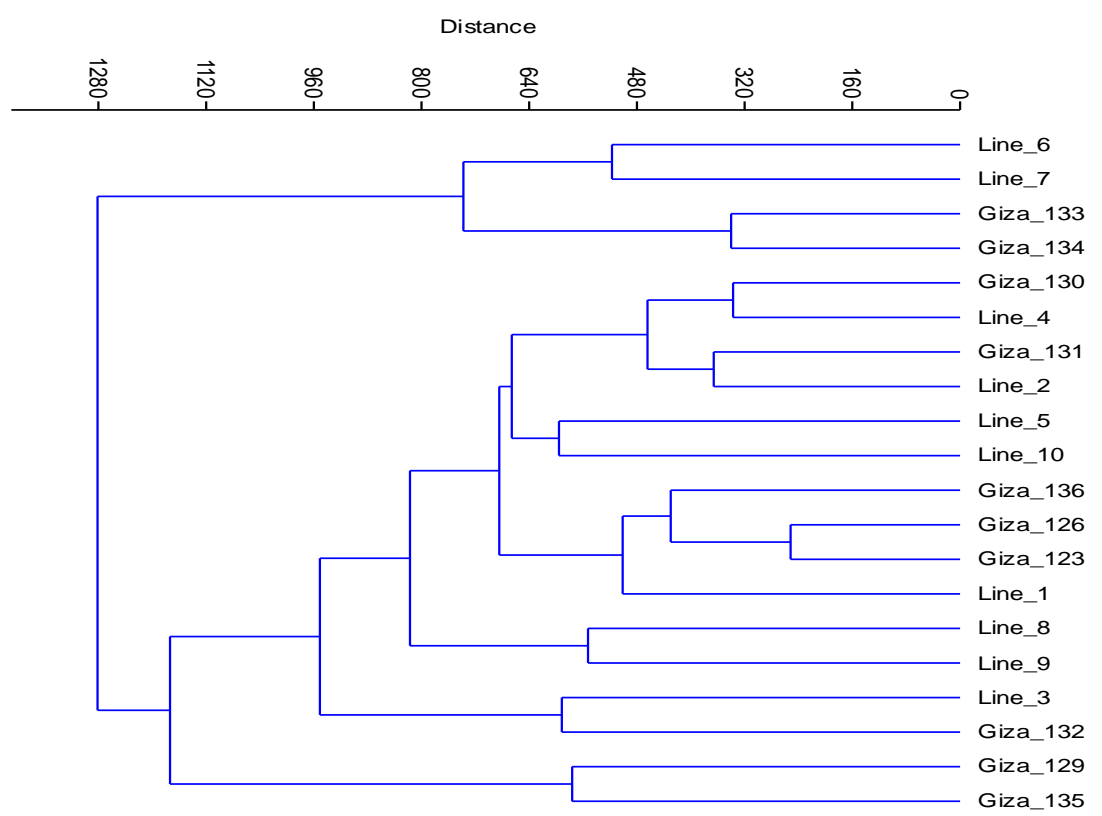

Fig. 1: Dendrogram presenting the classification of 20 barley genotypes tested at three environments (normal, water stress and saline soil) based on environments mean yield during 2014/2015 and 2015/2016 seasons.

\section{References}

Abd El-Wahab, S. A. (2002). Wheat response to Ascorbic Acid under different soil water stress. J. Agric. Mansoura Univ., 27 (6): 4205-4219.

Ahmed, I.A.; A.A. El-Sayed, R.A. Abo-El-Enin, A.S. El-Gamal, M.M. Noaman, A.M. ElSherbiny, F.A. Asaad, A.A. El-Hag, Kh.A. Moustata, A.M.O. El-Bawab, M.A. ElMoselhy, M.A. Megahed, M.M. Abdel-Hamed, Kh.A. Amer, A.A. Attia, M.F. Saad, M.A. Said, H.A. Ashmawy, R.A. Rizk and H.A.T. Mahfouz (2003). Giza 2000 , A new Egyptian barley variety for newly reclaimed lands and rainfed areas. Zagazig J. Agric. Res., 30 (6): 2095-2112.

Awad, H.A. (1997). Phenotypic stability for afrain yield and its contributing characters in durum wheat, Triticum turgidum L. var. Durum. Ann. Agric. Sci., 35: 181-194.

Bagheri, A. and H. HS. Abad (2007). Effect of drought and salt stresses on yield, yield components, and ion content of hull-less barley (Hordeum sativum L.). J. of new Agric. Sci., 3 (7): 1-15.

Bayoumi, T. Y. (2004). Diallel cross analysis for bread wheat under stress and normal irrigation treatments. Zagazig J. Agric. Res., 31 (2): 435455.

Ceccarelli, S. (1987). Yield potential and drought tolerance of segregating population of barley in contrasting environments. Euphetica, 36: 265273.

Eberhart, S. A. and W. A. Russell (1966). Stability parameters for comparing verities. Crop Sci., 6: 36-40.
Elakhdar, A.; T. Kumamaru, K. P. Smith, R. S. Brueggeman, L. J.A. Capo-chichi and S. Solanki (2017). Genotype by environment interactions (GEIs) for barley grain yield under salt stress condition. J. Crop Sci. Biotech., 20 (3): 193 - 204.

El-Denary, M. E. and E.E. El-Shawy (2014). Molecular and field analysis of some barley genotypes for water stress tolerance. Egypt. J. Genetics and Cytology, 43 (1):187-198.

El-Sayed, A.A. (2002). Improvement of food hullless barley in Egypt. Paper presented in the Food Barley Workshop organized by ICARDA and FAO, 14-17 January, 2002 Hammamet, Tunisia.

El-Seidy, E. H. E.; Kh. A. Amer; A. A. ElGammaal and E. E. El-Shawy (2012). Assessment of water stress tolerance in twenty barley genotypes under field conditions. Egypt J. Agric. Res., 90 (4): 325-345.

El-Seidy, E. H. E.; Kh. A. Amer; A. A. ElGammaal and E.E. El-Shawy (2013). Growth Analysis and Yield Response of Barley as Affected by Irrigation Regimes. Egypt J. Agron., 35(1):1-19

El-Shawy, E. E. A. (2008). Genetic analysis of some important traits of six-rowed barley in normal and saline affected fields. M. Sc. Thesis, Fac. Agric., Kafr El-Sheikh, Tanta Univ., Egypt.

EL-Shawy, E.E.; A. EL Sabagh, M. Mansour and C. Barutcular (2017). A comparative study for drought tolerance and yield stability in different genotypes of barley (Hordeum vulgare L.). J. Exp. Biol. Agric. Sci., 5 (2): 151-162.

Farhat, W.Z.E. (2005). Genetical studies on drought tolerance in bread wheat (Triticum aestivum L). M.sc. Thesis, Tanta Univ., Egypt. 
Fischer, R.A. (1984). Physiological limitations to producing wheat in semi-tropical and tropical environments and possible selection criteria. In: Wheats for More Tropical Environments. A Proceedings of the International Symposium, Mexico, D.F: CIMMYT, 209-230.

Gebremedhin, W. T. (2015). Adaptation of food barley (Hordeum vulgare L.) genotypes. Journal of Agricultural Sciences, 60 (2): 227-235.

Mansour, E.; E. S. A. Moustafa, N. Z. A. ElNaggar, A. Abdelsalam, and Ernesto Igartua (2018). Grain yield stability of high-yielding barley genotypes under Egyptian conditions for enhancing resilience to climate change. Crop and Pasture Sci., 69 (7): 681- 690.

Mansour, M.; E.E. El-Shawy and Sh. I. Abaas (2016). Genetic improvement of water stress tolerance in some barley genotypes. Egypt. J. Plant Breed., 20 (1):119-134.

Mariey, S. A. and R. A. Khedr (2017). Evaluation of some Egyptian barley cultivars under water stress conditions using drought tolerance indices and multivariate analysis. J. Sus. Agric. Sci., 43(2): 105- 114.

Mohamed, M. E. A. (2004). Genetical analysis and evaluation of drought tolerance trait under different conditions in wheat (Triticum aestivum L). Ph.D. thesis, Tanta Univ., Egypt.

Nabipour, A. R.; S. B. Yazdi; A.A. Zali and K. Poustini (2002). Effects of morphological traits and their relations to stress susceptibility index in several wheat genotypes. BIABAN. 7: 31-47.

Noaman, M.M. (2008). Barley development in Egypt. Proceedings of the $10^{\text {th }}$ International Barley Genetics Symposium, Alexandria, Egypt, 3-15.

Noaman, M.M.; A.A. El-Sayed, R.A. Abo ElEnein, I.A. Ahmed, A.S. El-Gamal, A.M. ElSherbiny, M.M. Abd El-Hameed, M.A. Megahed, M.A. Moselhy, A.M. El-Bawab, Kh.A. Amer, M.F. Saad, H.A. Ashmawy, R.A. Rizk and Y.M. Abdel Rawab (2006). Giza 132, a new drought-tolerant six-rowed barley cultivar. Egypt. J. Appl. Sci., 21: 46-58.

Samarah, N. H.; A. M. Alqudah; J. A. Amayreh and G. M. McAndrews (2009). The Effect of late-terminal drought stress on yield components of four barley cultivars. J. Agron. Crop Sci.,195 (6): 427- 441

Subhani, G. M.; A. J. Ahmad, J. Anwar, M. Hussain and A. Mahmood (2015). Identification of drought tolerant genotypes of barley (Hordeum vulgare L.) through stress tolerance indices. J. Animal \& Plant Sci., 25 (3): 686-692.

Vaezi, B.; V. Bavei and B. Shiran (2010). Screening of barley genotypes for drought tolerance by agro-physiological traits in field condition. African J. Agric. Res., 5 (9): 881-892. 


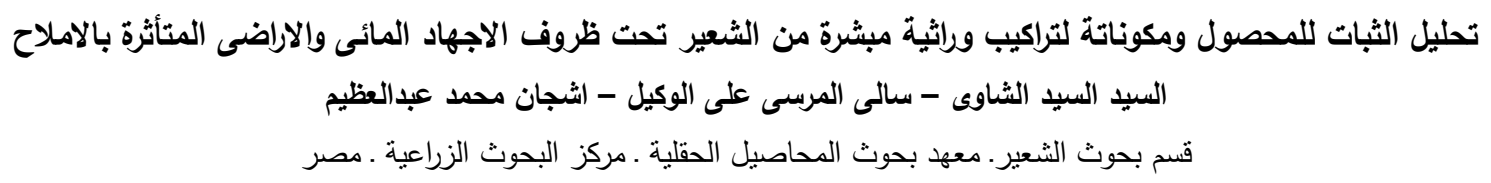

Corresponding author: sayedelshawy@gmail.com

يهدف هذا البحث إلى تقييم عشرين تراكيب وراثي من الثعير لتقييم أداءها في بيئات مختلفة. حيث يعتبر إنتاج تراكيب وراثية جديدة متأقلمة تحت الظروف البيئية المختلفة هو واحد من أهم أهداف برنامج التربية. تم دراسة هذة التراكيب الوراثية فى ثلاث بيئات مختلفة. ري طبيعي

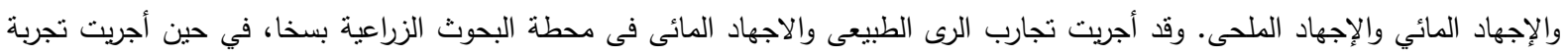

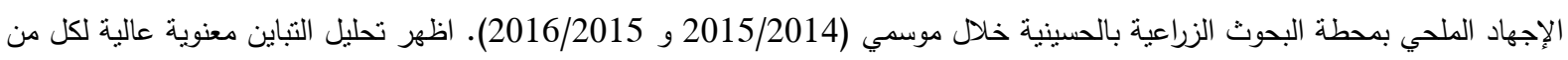
البيئات والتراكيب الوراثية والتفاعل بين التراكيب الوراثية والبيئة لكل التراكيب الوراثية المدروسة، وهذا مؤشر لضرورة تحليل الثبات المحصولى. وقد أظهرت النتائج ان أفضل التراكيب الوراثية هى جيزة 133 والسلالة 7 بالنسبة لمحصول الحبوب/فدان وكانت الأكثر ثباتاً، ولم يختلف معامل الانحدار (bi

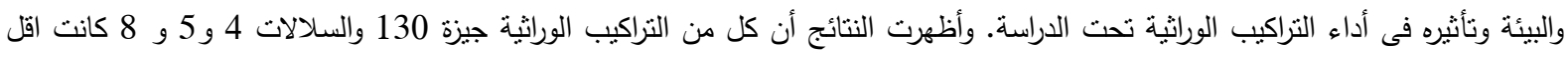

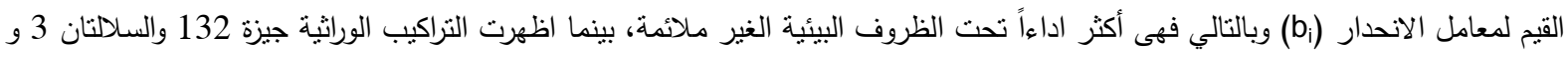
6 اداءاً أفضل تحت الظروف الطبيعية وحساسية للاجهادات البيئية المختلفة. 